\title{
Walking up the Down Escalator: Public Investment and Fiscal Stability
}

William Easterly, Timothy Irwin, and Luis Servén

When growth-promoting spending is cut so much that the present value of future government revenues falls by more than the immediate improvement in the cash deficit, fiscal adjustment becomes like walking up the down escalator. Although short-term cash flows matter, too tight a focus on them encourages governments to invest too little. Cash-flow targets also encourage governments to shift investment spending off budget by seeking private investment in public projects, irrespective of its real fiscal or economic benefits. To deal with this problem, some observers have suggested excluding certain investments (such as those undertaken by public enterprises deemed commercial or financed by multilaterals) from cash-flow targets. These stopgap remedies may help protect some investments, but they do not provide a satisfactory solution to the underlying problem. Governments can more effectively reduce the biases created by the focus on short-term cash flows by developing indicators of the long-term fiscal effects of their decisions, including accounting and economic measures of net worth, and, where appropriate, including such measures in fiscal targets or even fiscal rules. JEL codes: O23 E62 H60 H54

A popular phrase during the era of macroeconomic stabilization of the 1990s was "adjustment with growth." The focus of this article is on the surprising possibility that some types of fiscal austerity not only fail to bring growth, but they may not even bring "adjustment" in the long run.

Consider the following anecdote from the World Bank's own budgeting experience. In 1993 the World Bank Research Department unexpectedly produced a bestseller entitled The East Asia Miracle. The Research Department soon exhausted its administrative budget allocation for reprinting the book. The World Bank's centralized budget department denied a request for extra budgetary resources for printing more copies of the book on the grounds that the Research Department

(C) The Author 2008. Published by Oxford University Press on behalf of the International Bank for Reconstruction and Development / THE WORLD BANK. All rights reserved. For permissions, please e-mail: journals.permissions@oxfordjournals.org doi;10.1093/wbro/lkm014 Advance Access publication January 28, 2008 
had already exceeded its printing budget-even though producing more copies of the book would have more than paid for itself!

This kind of unreason is not confined to the world of bureaucratic budgetary management; it also extends to fiscal policy practice. The primary concern of most fiscal programs is to ensure public sector solvency, commonly viewed as an essential ingredient of macroeconomic stability. Solvency is by definition an intertemporal concept, relating to the present value of revenues and expenditures and encompassing both assets and liabilities. A cut in public investment that lowers growth will lower the present value of revenues; it is conceivable that the government's intertemporal position deteriorates at the same time as the cash deficit improves. In practice, however, it is customary to assess the strength of public finances almost exclusively on the basis of the cash deficit (or "overall balance")that is, the rate of acquisition of debt by the public sector.

Latin America offers a good illustration of this practice. There is rising concern across the region that the fiscal adjustment that many countries had to undertake since the early 1990s may have come with an excessive fall in public investment (figure 1). To the extent that the response of private investment has been insufficient to offset the decline of public investment in key sectors, such as infrastructure, current levels of public investment are perceived by many as too low to support long-term growth rates consistent with rapid poverty reduction.

Political economy considerations make adjustment difficult at the best of times. The recent backlash against free-market reforms in Latin America and the longstanding sensitivity to conditions perceived as imposed by outsiders make it more important than ever that adjustment programs be well conceived.

Figure 1. Primary Deficit and Public Infrastructure Investment in Latin America, 19802001

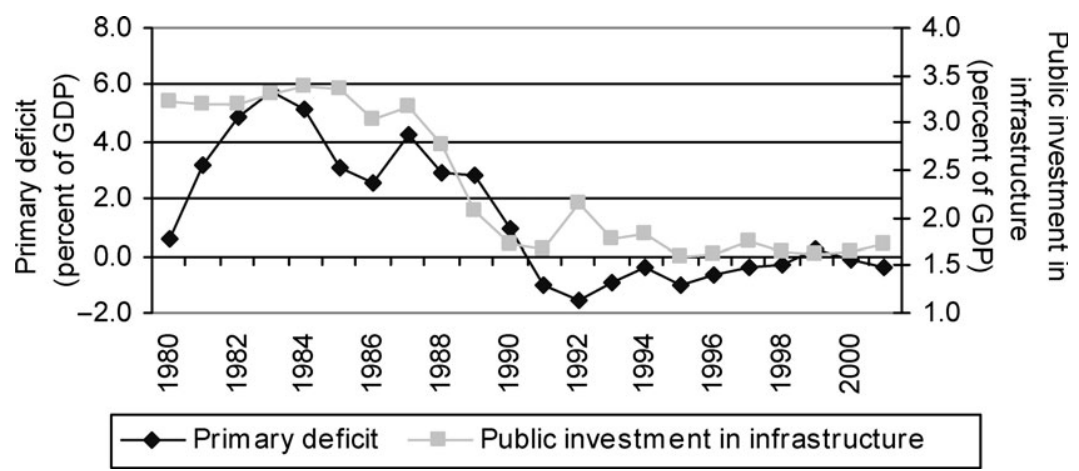

Note: Figure is based on data from Argentina, Bolivia, Brazil, Chile, Colombia, Costa Rica, Mexico, and Peru. Source: Calderón and Servén (2004). 
The international evidence suggests that Latin America's experience is the rule rather than the exception. Declines in infrastructure spending often account for the lion's share of fiscal deficit reduction, as Hicks (1991) shows for developing economies in a cross-regional context, Easterly and Servén (2003) show for Latin America, and Estache (2004) shows for Sub-Saharan Africa. For industrial countries, Roubini and Sachs (1989) and De Haan et al. (1996) find that capital expenditure falls disproportionately at times of fiscal stringency. Balassone and Franco (2000) show that fulfillment of the Maastricht deficit targets sped the decline of public investment in the European Union (figure 2): of the nine countries that exceeded the deficit target in 1992, eight met it in 1997. In all eight, public investment had fallen relative to GDP; in seven of them, it had also fallen relative to total primary expenditure. In contrast, three of the six countries that met the target in 1992 raised their public investment in the subsequent years.

The tendency toward compression of public investment at times of fiscal austerity underlies the fact that investment is the most volatile of all public spending items, as Talvi and Végh (2000) document using data from developing economies and Lane (2003) documents using data from industrial countries. Of course, declining public investment would be of little consequence if it reflected improved spending efficiency or were fully matched by increased investment by the private sector. In most countries in Latin America, the only developing region for which adequate data are available, this may have been the case in the telecommunications sector. But the evidence suggests that in most infrastructure sectors in most countries, private investment did not offset public sector retrenchment (Calderón and Servén 2004).

Declining investment is a cause for concern when it results in decreased accumulation of public capital and public capital is productive. This is not always

Figure 2. Primary Deficit and Public Investment in the European Union, 1980-2002

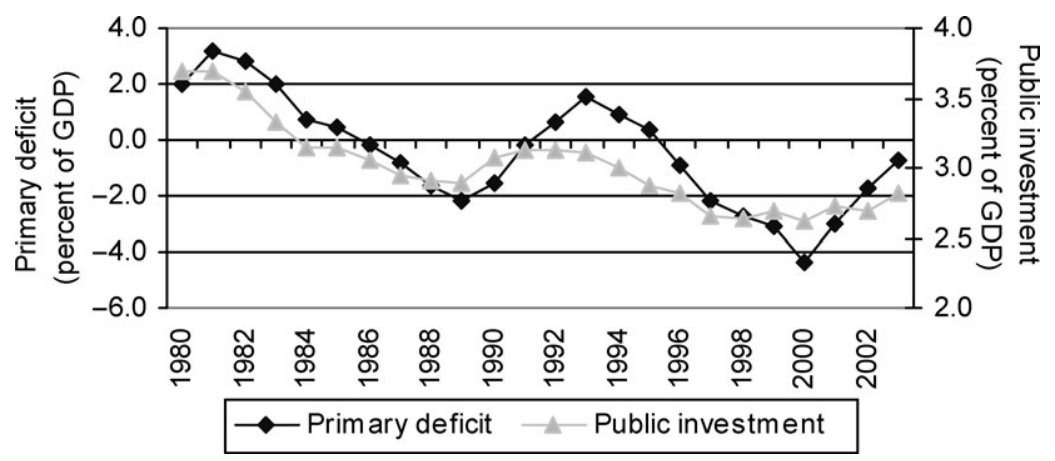

Note: Figure is based on data from Austria, Belgium, Finland, France, Germany, Spain, Sweden, and the United Kingdom.

Source: OECD Economic Outlook database. 
the case; many projects labeled as public investment can be white elephants, which bring no future output benefits. The link between public investment spending and capital accumulation can be fragile if investment involves significant waste-when projects are poorly selected and public procurement is inefficient or beset by corruption, for example (Pritchett 2000). With weak governance, public investment may become a vehicle for dispensing political favors rather than acquiring productive assets (Keefer and Knack 2007).

The empirical literature is far from unanimous on the contribution of public capital to aggregate output or growth; this lack of agreement is hardly surprising in the context of growth empirics. Nevertheless, most studies, especially the more recent ones, do find a positive impact. The conclusions appear to depend in part on the approach followed: studies using measures of physical infrastructure assets find significantly positive output contributions in the vast majority of instances, whereas those that measure public capital using cumulative investment flows tend to be less conclusive, likely for the reasons outlined in the preceding paragraph. In some cases, however, both approaches yield similar results; using both financial and physical measures of public capita, for example, Ferreira and Araujo (2005) find significantly positive output effects in Brazil.

Moreover, even if wasteful public investment spending weakens the link between spending and outcomes, an across-the-board reduction in public investment will still result in cuts in productive infrastructure projects. Sacrificing such projects weakens the economy's growth potential; the right response is instead to protect high-return projects from spending cuts. If government does otherwise, it is trying to walk up the down escalator.

This article offers a selective overview of these issues. It draws from the Latin American experience, because it has been relatively well documented, but its concerns are much more general. Indeed, they cut across developing as well as industrial regions, although they are more pressing in developing countries, which still have a long way to go in building up their infrastructure capital stocks. The article draws policy implications for the design and monitoring of fiscal targets consistent with both solvency and the efficient utilization of fiscal resources.

The article is organized as follows. The next section reviews the shortcomings of the current approach to fiscal discipline. The second and third sections deal with two types of remedies: granting exceptions to existing fiscal targets and introducing new targets. The last section offers some concluding comments.

\section{Shortcomings of the Standard Approach to Fiscal Discipline}

Fiscal adjustment programs typically focus on the short-term time path of the government's cash deficit, whose measurement is usually the center of attention 
of fiscal accounting. Short-term cash deficits and debt are the key fiscal concern of official creditors and form the basis of loan conditions in the fiscal and macroeconomic dimensions. They are also closely scrutinized by multilateral institutions, private creditors and investors, and economic analysts.

There are good reasons why these fiscal aggregates should be closely watched. The cash deficit approximates the government's financing needs, which are a primary concern for the fiscal authorities as well as financial market participants. It can also give an indication of the public sector's contribution to overall aggregate demand and thus its stance from the viewpoint of short-term stabilization, although the primary deficit (which excludes interest payments) may be preferable for this purpose.

Debt and the cash deficit can be misleading as solvency measures, however, because they do not take into account the assets and future income the government may acquire by incurring debt today. This, of course, is hardly surprising: liquidity and solvency are fundamentally different concepts; as in corporate finance, different indicators are needed to gauge them. A corporation does not seek to maximize just this year's cash flow; it seeks to maximize the present discounted value of all future cash flows. Telling the public sector to improve the cash balance no matter what would be like telling Apple to forgo investing in a new iPod ${ }^{\circledR}$ factory in order to improve this year's cash flow.

Solvency assessments based on debt and the cash deficit implicitly treat all public expenditures in the same way, because they all pose the same claim on today's fiscal resources. This blurs the distinction between public investment and public consumption and, more precisely, between expenditures that yield future fiscal benefits and those that do not-even though they may have radically different implications for tomorrow's public revenues and therefore for solvency itself.

Such practice distorts the tradeoffs faced by fiscal policy, both across time and among different kinds of public expenditures. Across time, binding debt and cash deficit targets today tend to encourage postponement of expenditures and advancement of tomorrow's revenues, even if their present value, which is the relevant concern for solvency, remains unchanged (or declines as a result of delaying urgently needed expenditures, for example). Across expenditure types, liquidity targets pose a one-for-one tradeoff at the margin, regardless of the type of expenditures involved, whereas solvency targets do not. Faced with these tradeoffs, governments having to strengthen public finances frequently choose adjustment paths that, by altering the time profile, the composition of expenditures, or both, attain the prescribed liquidity targets without any significant improvement in solvency. They resort to deferring payments to the first day of the next year, accumulating arrears to government workers or suppliers, advancing the collection of taxes, awarding higher pensions instead of increased wages, or granting guarantees instead of subsidies. Easterly (1999) and Easterly and Servén (2003) provide a variety of examples of this kind of illusory fiscal adjustment. 
Thus, other things being equal, governments facing binding liquidity targets today may devote too few resources to expenditures that yield returns tomorrow. This effect of liquidity targets on public spending composition is additional to the biases introduced by other political economy factors. These factors (which include governments' short-time horizons and political clientelism) can distort spending choices by discouraging public expenditures whose benefits accrue in the future in favor of those with immediate fiscal or political payoffs. Far from correcting these distortions, the conventional approach to fiscal discipline magnifies them.

If fiscal adjustment disproportionately cuts infrastructure spending that enhances growth, it can lead to a vicious circle in which low growth generates unsustainable debt dynamics, which force fiscal adjustment implemented through investment cuts, which lowers growth further and prompts additional fiscal retrenchment and investment cuts. In other words, if debt stabilization is pursued primarily by cutting productive spending, destabilization can ensue.

This phenomenon has been documented in both industrial and developing countries. In industrial countries, Alesina and Perotti (1997) find that fiscal corrections based primarily on public investment contraction are typically unsuccessful: they have an adverse effect on growth, and their stabilizing effect on public finances is eventually reversed. Calderón and Servén (2003) review the impact of public investment cuts in selected Latin American countries over the past decade. Their calculations suggest that the ensuing slump in growth and tax collection may have greatly weakened the intended solvency-enhancing effects of the capital expenditure decline.

These issues concern all kinds of public expenditures that generate future fiscal benefits. Public infrastructure investment is the leading example, to the extent that public capital yields financial returns that the government can capture. Conceptually, infrastructure investments can be divided into three groups:

- Investment that generates direct financial returns through user fees, such as ports, airports, railways, and toll roads.

- Investment that does not generate user fees but increases growth and future tax collection.

- Investment that generates no future fiscal or growth benefits, whether or not the project has a positive social return (as in the case of environmental projects).

The first two types of projects may pay for themselves - that is, generate a stream of financial returns whose present value exceeds the cost of the projects. On solvency grounds, deficit financing of those projects-termed "selfliquidating" (Mintz and Smart 2007) —is most likely to be justified, because such projects increase government net worth, even if they raise public debt in the short run. In practice, for the projects to increase government net worth, 
the government must be able to capture the returns. For the first type of projects, user fees must be sufficient to cover project costs; for the second type of projects, taxes must be high enough to translate the additional growth into sufficient additional revenues.

In the absence of user fees, many growth-enhancing projects may fail to generate sufficient tax revenues to cover their cost. With the low (marginal) tax collection rates of many developing economies, the growth impacts have to be considerable to yield the required tax revenue increases. For example, with a tax rate of 0.2 , the output contribution would have to be five times as high as the project's user cost for the government to break even. So if the user cost is about 10 percent (say, a 5 percent real interest rate and a 5 percent rate of depreciation), the project's marginal productivity must be at least 50 percent for the given tax rate to yield sufficient revenues (see Servén 2007 for the analytics of this and similar calculations).

Such high productivity is more likely to arise in situations in which the initial endowment of public capital is low (relative to that of other productive assets) specifically, when public capital services are substantially underprovided so that the marginal product of capital exceeds its user cost by a wide margin. Empirically, the international evidence appears to be consistent with the view that the marginal productivity of infrastructure capital is higher in developing economies, especially poorer ones, than in industrial countries (Calderón and Servén 2007).

Probably as a reflection of these country-specific ingredients, empirical results are mixed regarding whether public investment may be self-financing through its growth and tax-collection effects. Perotti (2004) examines this issue in five countries in the Organisation for Economic Co-operation and Development (OECD), using a vector autoregression approach. He finds that in Canada and the United Kingdom, the extra public capital makes a negative growth contribution; in Australia and the United States, the growth and tax collection effects finance only 20-30 percent of the investment cost. Only in Germany do these effects finance more than 100 percent of the cost. Using similar techniques but a broader sample of industrial countries, Pereira and Pinho (2006) find that public investment is roughly self-financing in France, Greece, and Ireland and more than self-financing in Germany and Italy. The growth effects are large in the majority of countries considered.

Because developing economies possess smaller infrastructure capital endowments than industrial countries do, infrastructure capital might be expected to have a higher marginal productivity and so to come closer to being self-financing. Ferreira and Araujo (2005) find that public infrastructure investment is selffinancing in Brazil, although it takes 10 years or more for the government to collect sufficient tax revenues to recoup the investment cost. 
Even if public sector projects fall in the intermediate area of having high returns for the economy as a whole but insufficient returns for public finances to improve public sector solvency, it may still be suboptimal to cut such projects during periods of fiscal austerity. An ideal marginal revenue collection scheme would allow the public sector to capture the returns, thereby eliminating the wedge between economywide and public sector returns. After all, the business of the public sector is precisely to provide public goods that yield a high return for the economy as a whole.

In addition, public investment projects are more likely to exhibit higher marginal productivity ex post if the government's ex ante project evaluation capabilities are sufficiently strong that they select high-return projects and reject lowreturn ones. This, however, is far from assured in practice. Many developing economies lack ex ante and even ex post project evaluation capabilities. (One exception is Chile, which has thorough procedures for evaluating projects; Fontaine 1997.)

Unconditional endorsement of public infrastructure spending would lead to wasteful investments, as Tanzi and Davoodi (2002) convincingly argue. Roads would be built to nowhere, and useful roads would not be maintained. Power plants would lie idle after being built too far ahead of demand. Water supply networks would be fully used but still burden the budget, because the tariff increases on which their financial viability was predicated were not allowed. Some investments would be well motivated but poorly informed; others would be motivated by bribes, patronage, or photo opportunities (Keefer and Knack 2007).

Infrastructure investment is the expenditure item that has attracted most attention in the ongoing debate about the design of fiscal policy. But the link between spending composition and solvency arises in a broader context. On the one hand, not all public investment projects yield future income to the government. On the other hand, some current expenditures do yield future fiscal returns. Infrastructure operation and maintenance expenditure is a case in point. Operation and maintenance determines the useful life of capital and hence has a "capital-creating" effect similar to that of investment. If public capital yields financial returns to the government, so does operation and maintenance. In fact, the financial, as well as social, return on operation and maintenance expenditure may well exceed that of new capital when the assets are not being properly maintained (Rioja 2003a, b; Kalaitzidakis and Kalyvitis 2004; Servén 2007).

This does not imply that developing countries should rush to raise public investment or that, as a rule, public investment increases should be financed with debt (or in any other particular way). The decision to invest should be guided by the return on the investment. That return is determined primarily by the marginal productivity of public capital, itself dependent on the government's ability to select good projects and the (relative) scarcity of services rendered by public capital (for example, the availability of infrastructure services). Both return and 
cost calculations should embody risk adjustments to take account of uncertainty. Indeed, assessments of the effect on net worth of public investment projects should err on the side of caution, particularly when the government's initial indebtedness is high, because in such cases even small changes in interest rates may have very large adverse effects on public finances.

\section{Excluding Certain Public Investments from Fiscal Targets}

Broadly speaking, there are two possible ways to address the bias against productive public spending implicit in existing fiscal targets. One is to retain the targets but exempt from their action certain public investments deemed more likely to enhance growth and solvency. The other is to adopt new fiscal targets. This section reviews the first alternative; the next section discusses the second.

\section{Privately Financing Public Investment Projects}

One way to place investment projects beyond the reach of short-term deficit and debt targets is to have private firms finance them. Indeed, across the developing world, many governments have turned to the private sector to finance new investments. In Latin America, for example, many governments have privatized their telecommunications firms and parts of their power and water industries. In the transport sector, private firms are often engaged in public-private partnerships in which the government retains an important financial role but the private sector finances investment. Chile and Colombia have had roads privately financed under arrangements in which the government provides revenue or foreign exchange guarantees. Other countries have begun to use a different form of public-private partnership in which a private firm finances an asset (such as a school, hospital, or prison), but the government purchases the service under a long-term contract.

These arrangements may improve the returns to investment and thus enhance government solvency. In many cases, however, concerns about efficiency and solvency have played a minor role, and the resort to private financing has been guided primarily by the desire to evade the pressure of liquidity targets on public investment. Projects conceived with such a purpose in mind may not be well designed from the point of view of efficiency or solvency.

The difference between liquidity and solvency effects is particularly apparent in privately financed projects in which the government purchases the service under a long-term contract. In such projects, explicit debt is replaced by similar commitments that are typically off balance sheet, without any major change in the magnitude of the government's financial obligations. It is also apparent when the government provides guarantees to private investors - such as guarantees of the 
private firm's debt or revenue - that leave the public sector bearing much of the investment risk (Hemming and International Monetary Fund 2006; Irwin 2007b). Even when such guarantees are not formally offered ex ante, they may be provided ex post through renegotiation of concession agreements. The bailout of the Mexican toll road program in 1997, for example, cost 1.0-1.7 percent of GDP (World Bank 2005; see also Guasch 2004).

On the whole, private financing has not come to play the dominant role in the provision of infrastructure services in Latin America or elsewhere that some observers expected. Although private financing now dominates telecommunications and some other infrastructure industries in some countries, it still plays a small role in roads and water and sanitation-something that is unlikely to change in the near term. Moreover, it would be undesirable for decisions about the ownership of infrastructure firms to be driven by short-term fiscal constraints. When private ownership works better than public ownership in terms of efficiency, equity, or both, a state-owned firm should be privatized, even if ownership of the firm requires little investment. Likewise, when public ownership works better, the firm should remain public, even if major investment is required. Private financing may thus lessen the problem caused by liquidity targets in certain cases, but it is not an appropriate response to the general problem.

\section{Excluding Specific Public Projects}

Another option is to exclude from fiscal targets certain investments undertaken by the public sector. A recent proposal would exclude projects financed by multilateral institutions on the grounds that such projects are more likely than others to be carefully screened and designed. This idea has not garnered much support, partly because the fungibility of money means that the marginal financing from multilateral institutions would not necessarily support the intended projects. Furthermore, in many developing economies, total multilateral flows are too small to make a big difference.

A second proposal, developed and refined by the International Monetary Fund (IMF 2004), is to exclude from fiscal targets investments by public enterprises that are deemed to be commercially run. This proposal (which is not new; see Afonso 2005) is, in principle, potentially important for countries in which public enterprises are included in the public sector aggregates monitored under fiscal programs. This is the case in Latin America but not in most other regions.

In practice, this approach poses several problems. First, appropriate criteria to identify commercially oriented public enterprises are difficult to establish. Second, the fact that enterprises that meet likely criteria are the exception rather than the rule in many countries (IMF 2005) detracts from the practical relevance of this approach for public investment. 
Another difficulty is that excluding commercially run public enterprises from targets may further restrict investment elsewhere in the public sector if those enterprises make a positive net contribution to the aggregate budget surplus. Exclusion of those enterprises would then make fiscal targets more, rather than less, stringent for productive public expenditure. One way around this difficulty is to exclude the investments, but not the savings, of these firms from fiscal targets. Doing so, however, adds complexity, which detracts from the transparency of the approach. An alternative would be to relax the targets by the net saving of the excluded public enterprises.

The fundamental problem with this proposal is that investments by enterprises that are not commercially run may still have offsetting fiscal and economic benefits - as is the case of many investments in roads, for example. In other words, the investments of commercially run public enterprises may not be the ones with highest priority from a fiscal or social perspective. Removing restrictions only on investment by commercially run public enterprises may still leave an overall public investment program far removed from the socially desirable one. For example, it is unlikely that Brazil's infrastructure needs would be significantly alleviated by allowing more investment by the commercially run public oil company PETROBRAS. Such outcomes are a general problem with any proposals on the basis of the special treatment of specific investments.

\section{Developing New Fiscal Targets Incorporating Measures of Net Worth}

The limitations of "selective" approaches that exempt certain investments suggest that it is important to consider more fundamental changes, in particular, whether governments can develop measures of net worth that are sufficiently accurate and objective to be used as a basis for fiscal targets. Measuring net worth-the difference between the value of assets and the value of liabilities-requires forecasts. The value of an asset is the present value of the net revenues it will generate and such revenues that are usually uncertain. Likewise, the value of a liability is the present value of the payments it will cause the government to make, and such payments are often uncertain. Because of these uncertainties, indicators of net worth are inherently approximate.

Governments seeking to beautify their reported fiscal positions can take advantage of uncertainty to overestimate future revenues and underestimate future costs. Governments seeking to protect some category of public spending on political grounds can exaggerate the value of the "assets" it creates, even if the spending is actually wasteful. If an indicator of net worth is too vulnerable to such manipulation it has too little credibility to be useful. 
Two indicators are used to measure net worth, one generated by modern accrual accounting, the other by long-term fiscal projections. This section examines the accuracy and reliability of each.

\section{Modern Accrual Accounting}

Like traditional cash accounts, modern accrual accounts include information on short-term cash flows. Unlike traditional cash accounts, accrual accounts also include a balance sheet showing assets and liabilities. As a result, accrual accounts generate a measure of net worth. They also include a measure of the surplus or deficit that is not based on current cash flows. That measure includes revenues that have been earned but are not yet collected and bills that are payable but not yet paid. Crucially, investment itself is not counted as an expense in the period of investment; only the depreciation of the investment is included. The difference between accrual revenues and accrual expenses gives an incomestatement surplus that is roughly equal to the increase in the government's net worth.

To see the implications of accrual accounting, consider a government investing $\$ 200$ million in a power plant, financed entirely by borrowing (this example is taken from Irwin 2007a). Assume that, in the first year, no revenue is received, no operating costs are incurred, and no depreciation occurs. Under cash accounting, the government's accounts show $\$ 200$ million in extra expenditure, which increases the cash deficit and debt by the same amount (table 1). Under modern accrual accounting (table 2), these consequences of the investment on the government's cash flows and debt are revealed, but so, too, are the consequences for the government's assets. The accounts report that the investment has no net effect on the government's net worth or income-statement surplus.

Accrual-based accounting standards for financial reporting have the advantage of being designed to limit the self-serving bias that uncertainty makes possible. Most obviously, financial reports, whether based on cash or accrual accounting,

Table 1. Debt-Financed Investment in Cash Accounting

\begin{tabular}{lc}
\hline Item & Amount $(\$$ million $)$ \\
\hline Revenues & 0 \\
Expenditure & 200 \\
Surplus & -200 \\
Debt & 200 \\
\hline
\end{tabular}

Note: Cash surplus is the sum of cash disbursed to operations and cash disbursed to investment. Source: Authors. 
Table 2. Debt-Financed Investment in Modern Accrual Accounting

\begin{tabular}{lr}
\hline Item & Amount (\$ million) \\
\hline Income statement & 0 \\
Revenue & 0 \\
Expenses & 0 \\
$\quad$ Income-statement surplus & \\
Balance sheet & 200 \\
Assets & 200 \\
Liabilities & 0 \\
Net worth & 200 \\
Cash-flow statement & -200 \\
Cash disbursed to investment & 200 \\
Cash surplus & \\
Cash from financing & \\
\hline Note: Cash surplus is the sum of cash disbursed to operations and cash disbursed to investment. \\
Source: Authors.
\end{tabular}

must be audited by an independent auditor. In addition, accrual accounting standards tackle bias by preferring measures that are objectively verifiable even at the cost of some relevance. Some standards, for example, require an asset to be valued by recording its acquisition cost and then depreciating the cost according to a simple formula. The resulting value can only approximate the asset's true value, but the measure is less vulnerable to bias than alternative measures. When standards require the reporting of market value, they sometimes require the valuation to be performed by an independent expert (other than the auditor). Accounting scandals show that these safeguards can fail to prevent biased reporting, but they are surely better than nothing. Moreover, although the risk of misleading accrual information is real, it does not provide a strong argument against the adoption of accrual accounting, because cash-based reporting is at least as vulnerable to manipulation, as argued earlier.

Reporting according to modern accrual accounting standards is, however, more costly than reporting according to cash standards, and it can take years for a government to move from cash to accrual accounting. These costs are more likely to be justified in middle- and high-income countries than in the poorest developing economies. Many high-income countries (including Australia, Canada, New Zealand, the United Kingdom, and the United States) have already made the transition, and many middle-income countries (including Chile, Indonesia, the Philippines, and South Africa) are adopting accrual accounting.

Although accrual accounting generates valuable information missed by traditional cash accounting, it is not sufficient for the assessment of net worth, even 
in middle- and high-income countries. For one thing, accounting values can diverge too much from true values. After many years of inflation, the depreciated acquisition cost of an asset may greatly underestimate the present value of the cash flows it will generate. In addition, accounting values of assets that generate user fees and higher tax payments at best capture only the value of the user fees, because the present value of future tax revenues does not count as an asset from the conventional accounting perspective. In contrast, durables are generally treated as assets and valued at their depreciated acquisition or replacement cost, even if they generate no future cash flows from either user fees or taxes. Expenditure on a bridge to nowhere can create an accounting asset even if it generates no tolls and does nothing to increase economic output.

\section{Long-Term Fiscal Projections}

Long-term fiscal projections have the potential to remedy some of the shortcomings of accrual accounting. Such projections, prepared in various ways by countries such as Australia, New Zealand, the United Kingdom, and the United States, can include estimates of the government's operating and investing cash flows over the next 50-75 years, which can then be discounted back to the present to arrive at an estimate of the government's net worth. Crucially, all expected cash flows under current policies can be projected, including taxes and welfare expenditure.

The projections can include public investment, expenditure on operations and maintenance, and payments to privately financed firms in public-private partnerships. Revenues from user fees can be included. If evidence suggests that some investments increase tax revenue by generating more taxable economic activity, this extra revenue can also be included.

Long-term fiscal projections can be designed to take account of the uncertainty of future cash flows. On the one hand, future revenues and expenditure can be adjusted for risk: risky tax revenues, for example, can be discounted at a higher rate than more predictable pension spending. On the other hand, the projections can show how net worth changes with critical assumptions about life expectancy, health care costs, and output. If output is modeled as a function of the stock of public capital, the projections can show how sensitive the government's net worth is to this assumption.

The biggest disadvantage of long-term projections is a corollary of their usefulness: generating the relevant information requires estimates that are subject to enormous uncertainty. What will the future rate of growth of GDP be? How will it be affected, if at all, by public investment? The large extent of reasonable disagreement about such estimates implies a large range of reasonable estimates of the government's net worth. This makes room for self-serving projections. 
Table 3. Benefits and Drawbacks of Alternative Sources of Fiscal Indicators

\begin{tabular}{llll}
\hline Feature & Cash accounting & $\begin{array}{l}\text { Modern accrual } \\
\text { accounting }\end{array}$ & $\begin{array}{l}\text { Long-term } \\
\text { projections }\end{array}$ \\
\hline $\begin{array}{l}\text { Provides information on short-term } \\
\text { cash flows }\end{array}$ & Yes & Yes & Yes \\
$\begin{array}{l}\text { Provides information on net worth, } \\
\text { given current policies }\end{array}$ & No & Partially & Yes \\
$\begin{array}{l}\text { Incorporates uncertainty } \\
\text { Limits self-serving forecast bias }\end{array}$ & Avoids the issue & Partially & Yes \\
\hline
\end{tabular}

Source: Authors.

Though uncertainty in the estimates is unavoidable, a government can make its projections more credible. It can allow others to see how the results are generated by making its projection model publicly available (in a spreadsheet on the Internet, for example). For critical parameters or key variables, it can use the estimates of a panel of independent experts, as Chile does in estimating its structural surplus. It can prepare and publish standards that it will follow in making the projections. And it can legislate that an independent auditor must opine on whether the projections follow those standards and reflect the stated assumptions. International organizations and financial institutions could help develop the standards and expertise necessary for some of these steps.

Each approach has benefits and drawbacks (table 3). Cash accounting offers the necessary information on liquidity and, because of its short-term focus, limits opportunities for some sorts of bias, but it provides no information on the crucial issue of government net worth. Modern accrual accounting fills this gap using methods designed to limit bias, but partly because of the concern to limit bias, it includes some poor estimates of values and provides no information on crucial elements such as future tax revenues. Long-term projections can overcome these problems, but only at the cost of requiring more estimates, creating more leeway for bias. Given the advantages and disadvantages of each approach, the best strategy, at least for middle- and high-income countries, would seem to be for governments to develop both accrual accounting and long-term projections while continuing to monitor short-term cash flows.

\section{Fiscal Targets and Fiscal Rules}

Indicators of net worth can also form the basis for new fiscal targets and rules that promote solvency without sacrificing public investment. One alternative is the so-called golden rule, according to which governments can borrow only to 
invest in the creation of new assets. This idea of separating the current and capital budgets is hardly new, but it has recently been revived (a classic reference is Musgrave 1939; see Bassetto and Sargent 2005 for historical background). The British government has adopted a version of the golden rule that "over the economic cycle" allows it to borrow only to invest and only as long as public sector net debt remains below 40 percent of GDP (H.M. Treasury 2004).

Accrual accounting suits the golden rule, because another way of stating the rule is to say that governments must not run an income-statement deficit (that is, they must not reduce their net worth). Because the income-statement surplus excludes expenditure on investment, the golden rule encourages investment. Because the income-statement surplus includes depreciation, however, adopting the golden rule is not the same as simply exempting investment from the fiscal targets-it amounts to exempting net investment from fiscal targets. Observance of the golden rule over a long period of time would eventually result in a public debt stock no larger than the public capital stock so that to a first approximation the outstanding debt would be fully backed by public assets.

The limitations of typical accounting mean that the golden rule does not ensure solvency or even expected solvency. The reason is that the assets may not yield an expected return high enough to cover the interest on the debt that financed their acquisition. Furthermore, by treating current and capital spending differently, the golden rule offers an incentive for opportunistic misclassification of expenditures.

An alternative that, in principle, avoids these problems is the permanentbalance rule. Roughly stated, it requires governments to set tax rates at a constant fraction of output that over the long run pays for the government's present and future expenditure (Buiter and Grafe 2004). Named by analogy with Milton Friedman's permanent-income hypothesis, the rule allows governments to borrow when revenue is temporarily low or when current investment opportunities are greater than future investment opportunities. Long-term fiscal projections suit the permanent-balance rule, because such projections are required to determine the required minimum tax rate. Implementing the permanent-balance rule successfully would thus require addressing the problems discussed earlier about the reliability of long-term fiscal projections, which is no easy matter.

A compromise solution that avoids some of the problems with both the golden rule and the permanent-balance rule is the modified golden rule recently proposed by Mintz and Smart (2007). They suggest that governments should be able to borrow to invest in self-liquidating assets, such as power plants that generate future revenues for the government but not in assets that generate no revenues, such as typical public schools. Furthermore, just as firms do not finance all their assets with debt, governments should be limited to borrowing only some fraction of the value of the revenue-generating assets. These features would result in a rule that is 
more conducive to solvency than the golden rule, without relying as much on potentially unreliable long-term forecasts as does the permanent-balance rule.

\section{Conclusions}

In many industrial and developing economies, governments have cut back on public investment as they have brought their budgets closer to balance. Although budget cuts were probably necessary, the cuts in public investment may have been counterproductive, because much theory and evidence suggest that public investment has the potential to increase future output.

In the worst case, investment cuts trigger a vicious circle, in which the subsequent deterioration of future revenue forces further investment cuts, leading to yet further deterioration, further investment cuts, and so on. What is supposed to be fiscal adjustment in this case actually has the same consequences as fiscal profligacy. Cutting investment to promote solvency becomes the fiscal equivalent of walking up the down escalator-riders step up only to end up below where they started.

The cuts in public investment should have come as no surprise when most countries measure their fiscal position not in terms of net worth but in terms of short-term cash flows and gross debt, and cutting investment can reduce debt and short-term cash flows, even as it reduces net worth. The problem afflicts both industrial and developing economies, but it is more pressing in developing economies, which have not yet built up their public capital stocks.

The decline in public investment suggests the need to rethink fiscal strategies. In some cases, it may be best to increase public investment and accept a higher short-term cash deficit in exchange for higher tax and user-fee revenues later. This strategy is unlikely to be right for all countries, however. Those with good infrastructure and bad fiscal positions may indeed do well to cut public investment. Countries with high taxes and debt may do best to increase public investment but finance it by cutting current expenditure. Still others, with high debt and little room for cuts in current expenditure, may have no choice but to raise taxes or forgo improvements in their infrastructure. Each case must be analyzed on its merits, with-given the tendency to be optimistic in forecasting growth and the performance of investments - a degree of skepticism. One general lesson is that appropriate spending composition has to be an essential part of fiscal adjustment and consolidation strategies, because it affects growth outcomes. In other words, spending targets and growth forecasts cannot be set without regard to the composition of expenditure, as they currently are.

All governments are likely to benefit from better fiscal information. The idea is not to abandon measures of debt and short-term cash flows, which are clearly 
important, but rather to supplement them with measures of assets, yielding a measure of net worth and its change over time. What is needed is information that allows governments to quickly determine when improvements in short-term cash flows are coming at the expense of declining net worth. Two means of generating such information are constructing long-term projections of fiscal cash flows and adopting modern accrual accounting.

Better fiscal information is helpful irrespective of whether the government follows quantitative fiscal rules or targets. But the question also arises whether governments should set themselves fiscal rules or targets incorporating measures of investment or net worth. Because debt and short-term cash flows matter, rules or targets based exclusively on net worth may not be helpful. But combining net worth with conventional fiscal measures may have merit. The United Kingdom, which adopted a version of the golden rule combined with a debt target, offers one example. An even better option might be a modified golden rule that allows borrowing to finance a portion of the cost of cash-generating assets but also requires that some proportion be financed by current taxes. There is no obvious "best" solution, but whatever the specific solution chosen, it is clearly time to change the exclusive focus on public sector liabilities and bring public sector assets into the picture when designing fiscal adjustment. It is much easier to walk up the up escalator.

\section{Notes}

William Easterly is professor of economics at New York University, where he is also a faculty affiliate of Africa House and co-director of the Development Research Institute; his email address is william. easterly@nyu.edu. Timothy Irwin is a senior economist in the Finance, Economics, and Urban Department at the World Bank; his email address is tirwin@worldbank.org. Luis Servén (corresponding author) is research manager for macroeconomics and growth in the Development Research Group at the World Bank; his email address is lserven@worldbank.org. An earlier version of this article was prepared for the World Bank's Latin American Regional Studies Program. The authors are grateful to Penelope Brook, Antonio Estache, José Luis Irigoyen, Guillermo Perry, Sergio Rebelo, Augusto de la Torre, and three anonymous referees for helpful comments.

\section{References}

Afonso, J. 2005. "Fiscal Space and Public Sector Investment in Infrastructure." IPEA Texto para Discussao 1141, Instituto de Pesquisa Econômica Aplicada, Brasilia.

Alesina, A., and R. Perotti. 1997. "Fiscal Adjustments in OECD Countries: Composition and Macroeconomic Effects." International Monetary Fund Staff Papers 44:210-48.

Balassone, F., and D. Franco. 2000. "Public Investment, the Stability Pact and the Golden Rule." Fiscal Studies 21(2):207-29. 
Bassetto, M., and T. Sargent. 2005. "Politics and Efficiency of Separating Capital and Ordinary Government Budgets.” NBER Working Paper 11030, National Bureau of Economic Research, Cambridge, Mass.

Buiter, W., and C. Grafe. 2004. "Patching Up the Pact: Suggestions for Enhancing Fiscal Sustainability and Macroeconomic Stability in an Enlarged European Union." Economics of Transition 12(1):67-102.

Calderón, C., and L. Servén. 2004. "Trends in Infrastructure in Latin America.” World Bank Policy Research Working Paper 3400, Washington, D.C. 2007. "Is Infrastructure Capital Productive?” World Bank, Washington, D.C.

De Haan, J., J. Sturm, and B. Sikken. 1996. "Government Capital Formation: Explaining the Decline." Weltwirtschaftliches Archiv 132(1):55-74.

Easterly, W. 1999. "When Is Fiscal Adjustment an Illusion?” Economic Policy 14(28):55-86.

Easterly, W., and L. Servén. 2003. The Limits of Stabilization: Infrastructure, Public Deficits and Growth in Latin America. Stanford, Calif.: Stanford University Press.

Estache, A. 2004. "What Do We Know about Sub-Saharan Africa's Infrastructure and the Impact of Its 1990s Reforms?" World Bank, Washington, D.C.

Ferreira, P., and C. Araujo. 2005. "On the Economic and Fiscal Effects of Infrastructure Investment in Brazil.” Fundação Getulio Vargas da Escola de Pós-Graduação em Economia, Ensaio Econômico 613, São Paulo, Brazil.

Fontaine, E. 1997. "Project Evaluation Training and Public Investment in Chile." American Economic Review 87(2):63-7.

Guasch, J. Luis. 2004. Granting and Renegotiating Infrastructure Concessions: Doing It Right. WBI Development Studies. Washington, D.C.: World Bank.

Hemming, R., and International Monetary Fund. 2006. Public-Private Partnerships, Government Guarantees, and Fiscal Risk. Washington, D.C.: International Monetary Fund.

Hicks, N. 1991. "Expenditure Reductions in Developing Countries Revisited." Journal of International Development 3(1):29-37.

International Monetary Fund. 2004. "Public Investment and Fiscal Policy." Washington, D.C. 2005. "Public Investment and Fiscal Policy: Lessons from the Pilot Country Studies." Washington, D.C.

Irwin, T. 2007a. "Accrual Accounting, Long-Term Fiscal Projections, and Public Investment in Infrastructure." In G. Perry, L. Servén, and R. Suescún eds., Fiscal Policy, Stabilization, and Growth: Prudence or Abstinence? Washington, D.C.: World Bank.

2007b. Government Guarantees: Allocating and Valuing Risk in Privately Financed Infrastructure Projects. Washington, D.C.: World Bank.

Kalaitzidakis, P., and S. Kalyvitis. 2004. "On the Macroeconomic Implications of Maintenance in Public Capital." Journal of Public Economics 88(3-4):695-712.

Keefer, Philip, and Steven Knack. 2007. "Boondoggles, Rent-Seeking and Political Checks and Balances: Public Investment under Unaccountable Governments." Review of Economics and Statistics 89(3):566-72.

Lane, P. 2003. "The Cyclical Behavior of Fiscal Policy: Evidence from the OECD.” Journal of Public Economics 87(12):2661-75.

Mintz, J., and M. Smart. 2007. "Incentives for Public Investment under Fiscal Rules.” In G. Perry, L. Servén, and R. Suescún, eds., Fiscal Policy, Stabilization, and Growth: Prudence or Abstinence? Washington, D.C.: World Bank. 
Musgrave, R. 1939. "The Nature of Budgetary Balance and the Case for a Capital Budget." American Economic Review 29(2):260-71.

OECD. Various years. Economic Outlook. Paris.

Pereira, A., and M. Pinho. 2006. "Public Investment, Economic Performance and Budgetary Consolidation: VAR Evidence for the 12 Euro Countries." College of William and Mary, Department of Economics Discussion Paper 40, Williamsburg, Va.

Perotti, R. 2004. "Public Investment: Another (Different) Look." IGIER Working Paper 277, Innocenzo Gasparini Institute for Economic Research, Milan.

Pritchett, L. 2000. "The Tyranny of Concepts: CUDIE. Cumulated, Depreciated, Investment Effort Is Not Capital." Journal of Economic Growth 5(4):361-84.

Rioja, F. 2003a. "Filling Potholes: Macroeconomic Effects of Maintenance versus New Investments in Public Infrastructure." Journal of Public Economics 87(9-10):2281-304. $127-37$.

Roubini, N., and J. Sachs. 1989. "Government Spending and Budget Deficits in the Industrial Countries." Economic Policy 4(8):99-132.

Servén, L. 2007. "Fiscal Discipline, Public Investment, and Growth.” In G. Perry, L. Servén, and R. Suescún, eds., Fiscal Policy, Stabilization, and Growth: Prudence or Abstinence? Washington, D.C.: World Bank.

Talvi, E., and C. Végh. 2000. "Tax Base Variability and Procyclical Fiscal Policy.” NBER Working Paper 7499, National Bureau of Economic Research, Cambridge, Mass.

Tanzi, Vito, and Davoodi Hamid. 2002. "Corruption, Public Investment, and Growth." In George T. Abed, and Sanjeev Gupta, eds., Corruption and Economic Performance. Washington D.C.: International Monetary Fund.

Treasury, H.M. 2004. "Long-Term Public Finance Report: An Analysis of Fiscal Sustainability." December, London.

World Bank. 2005. Infrastructure in Latin America: Recent Developments and Key Challenges. Washington, D.C.: World Bank. 